\title{
Enhancement of Antibody Titers against Newcastle Disease Virus in Vaccinated Chicks by Administration of Phyto V7
}

\author{
Dan Perelman', Walter F. Goldman², Ruben J. Wernik ${ }^{2}$ and Gadi Borkow ${ }^{2}$ \\ ${ }^{1}$ Veterinary consultant, Ramat Efal, Israel \\ ${ }^{2}$ Immune Nutrition Inc., Rehovot, Israel
}

\begin{abstract}
Phyto V7 is a complex of phytochemicals that has been found to stimulate the immune responses in AIDS patients and in Human Papilloma Virus infected individuals. Here we report the capacity of Phyto V7 to stimulate humoral immune response in chicks vaccinated against Newcastle Disease Virus. The mean antibody titers against Newcastle Disease Virus were $>50 \%$ higher in chicks fed with Phyto V7 as compared to chicks fed with regular broiler feed $(p<0.01)$. While the exact mechanism by which Phyto V7 affects the immune system needs to be elucidated, this study clearly supports the notion that Phyto V7 has immune-stimulatory properties. Further studies are needed to clearly establish if Phyto V7 administration can increase successful vaccination rates against Newcastle Disease Virus and other viruses in chicks and other animals. The capacity of Phyto V7 to enhance immune responses in humans to vaccines should be studied too.
\end{abstract}

\section{Phytochemicals as Immune Stimulators}

Phytochemicals (PHT), chemical compounds that occur naturally in plants, beside of serving as bionutrients $[1,2]$, have been shown to enhance immune responses [3-7] and downregulate inflammatory reactions [8-10]. We have observed that administration of a specific PHT mix (Phyto V7) increased in situ cellular immune responses and clearance of High Risk Human Papilloma Virus (HR-HPV) in preneoplastic cervical lesions (manuscript in preparation). Furthermore, we have found that administration of Phyto V7 to AIDS patients significantly improved their well-being and CD4+ T-cell counts, whether or not they were receiving Highly Active Antiretroviral Therapy (manuscripts submitted for publication). Our aim in the current study was to determine if Phyto V7 can enhance specific humoral immune responses.

\section{Experimental}

In order to test if Phyto V7 can enhance specific humoral immune responses we examined if its administration to Broiler chickens that are immunized against Newcastle Disease Virus (NDV) can enhance the antibody titers against this virus. These chickens, which are bred and raised specifically for meat production, are the most consumed meat in Israel. Vaccination against NDV is the only vaccination which is obligatory for all poultry species in Israel. However, in spite of the obligatory vaccination programs there are still outbreaks of NDV disease in Israel, maybe because of inefficient immune responses.

Broiler chicks (Ross commercial strain) that originated from a single unvaccinated parent flock were obtained from an approved commercial hatchery (Kfar Daniel, Israel). The parent flock was 8 months old at the time the hatching eggs were collected for the Trial. The hatched chicks were kept in an isolated artificially ventilated building, under computer controlled temperature $\left(30^{\circ} \mathrm{C}\right.$ on Day 1 which was gradually reduced until reaching $22^{\circ} \mathrm{C}$ at Day 22 and kept at $22^{\circ} \mathrm{C}$ until the end of the experiment) according to the recommendations of the Ross Broiler Management 2009 Guide. The building contained 40 equal separate pens, housing 50 chicks each. Ten pens, spread at random over the building, were designated for the Trial. Five pens per group, containing a total of 250 chicks, were randomly selected to serve either as the Control Group (CG) or Test Group (TG). The CG was fed regular broiler feed. TG was fed with Phyto V7. Phyto V7 was mixed with the regular feed $(4.04 \mathrm{~kg} /$ ton from hatching until Day 20, and $6.77 \mathrm{~kg} / \mathrm{ton}$ from Day 21 to Day 37). These doses were chosen by extrapolating from successful doses used per weight in human trials (unpublished results) to the average weight of the chicks at the different ages. All 500 chicks were vaccinated against Newcastle Disease Virus according to the Israeli Veterinary Services Vaccination Program as follows: on the hatching day a live vaccine of Newcastle lentogenic $\mathrm{VH}$ viral stain (similar to Hitchner B1 strain) mixed with the Infectious Bronchitis Mass, H120 strain, were administered by spray at the hatchery. Twelve days later, each chick was injected I.M. with $0.3 \mathrm{ml}$ of a mix of inactivated Newcastle (VH strain) (Abic, Phibro Israel) and Infectious Bursal disease-Gumboro (FS2 strain, Abic, Phibro Israel). Finally, 19 days after hatching, all chicks were exposed to a live Newcastle vaccine (VH strain) administered as aerosol (mist, Abic, Phibro Israel). No other vaccinations were performed. One $\mathrm{ml}$ of blood samples were taken from the wing veins twice for evaluation of antibody titers against Newcastle disease virus. The first blood sample was taken 12 days after hatching to examine the effect of the first vaccination, as on Day 12 the second vaccination was administered. The second blood sample was taken 37 days after hatching, 2 days before slaughtering. The blood samples were collected randomly from 5 chicks in each pen, i.e. a total of 25 samples per each group per each blood collection day. The specific antibody titers were determined in an external independent lab (The Egg and Poultry Board Regional Laboratory, Beer-Tuvia, Israel) using a scale of 1 to 7 Hemagglutination Inhibition (HI) Units, being 1 a very low $\mathrm{Ab}$ titer and $7 \mathrm{a}$ high $\mathrm{Ab}$ titer.

\section{Results and Discussion}

Twelve days after hatching and undergoing a vaccination program against Newcastle Disease Virus, the mean and SD titers of Ab against

*Corresponding author: Gadi Borkow, Immune Nutrition Inc, Hameyasdim 44, Gibton 76910, Israel, E-mail: gadi@immunutr.com

Received August 12, 2013; Accepted September 23, 2013; Published September 26, 2013

Citation: Perelman D, Goldman WF, Wernik RJ, Borkow G (2013) Enhancement of Antibody Titers against Newcastle Disease Virus in Vaccinated Chicks by Administration of Phyto V7. J Vaccines Vaccin 4: 203. doi: 10.4172/21577560.1000203

Copyright: @ 2013 Perelman D, et al. This is an open-access article distributed under the terms of the Creative Commons Attribution License, which permits unrestricted use, distribution, and reproduction in any medium, provided the original author and source are credited. 

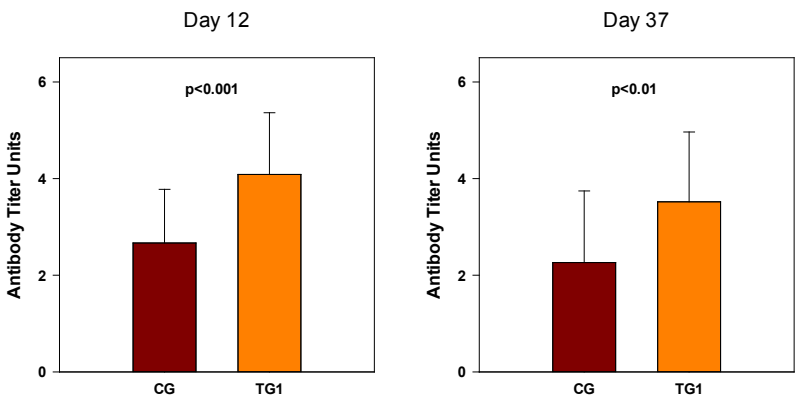

Figure 1: Antibody titers against Newcastle Disease Virus in chicks fed with regular broiler feed (Control Group - CG, $n=25$ ) or fed with Phyto V7 (Test Group - TG, n=25).

Newcastle Disease Virus in the Test and Control Groups were 4.09 \pm 1.28 and $2.67 \pm 1.11$ Units, respectively. As determined by a Rank Sum Test Analysis (Sigma Plot 12.0), the antibody titers in the Test Group was statistically significantly higher than in the Control Group $(\mathrm{p}<0.001$; Figure 1, left panel). Similarly, 37 days after hatching and 18 days after finishing the vaccination protocol, the mean and SD titers of Ab against Newcastle Disease Virus was higher in the Test Group than in the Control Group; $3.52 \pm 1.44$ vs. $2.26 \pm 1.48$ Units $(\mathrm{p}<0.01$; Figure 1, right panel). This study indicates that administration of Phyto V7 can enhance the immune responses induced by vaccination against Newcastle Disease Virus in chicks and probably to other viruses in animals and in humans. It has already been demonstrated that there is a very high correlation between antibody titers against NDV, hemagglutinin inhibition titers, and the achieved clinical protection of chicks against this virus [11-14]. For example, it has been determined that 400 and 600 Hemagglutinin units (HAU) raised by a vaccine can provide $50 \%$ clinical protection, while complete protection from morbidity and mortality can be achieved by 1000 HAU [11]. Thus the $\sim 55 \%$ increase in the antibody titers obtained by adding Phyto V7 to the chicks food may significantly improve the achieved clinical protection following NDV vaccination. Obviously in order to evaluate the full potential of Phyto V7 administration in the context of NDV vaccination, further studies are needed. These studies should include investigations of the kinetics of the antibody titer development against NDV under the influence of different doses of Phyto V7. These studies should also examine if administration of Phyto V7 has any effects on performance data of the chickens, such as on their body weight gain and food consumption rate.

The results of this study are in accordance with our previous observations that consumption of Phyto V7 stimulates the immune system. This was exemplified in HIV-1 infected individuals by the increase of their blood CD4+ T-Cell counts (manuscripts submitted for publication) and in women infected with HR-HPV, by the increase of the CD4+ T-cell counts in cervical smears and in increased clearance of the DNA-HPV in the preneoplastic cervical lesions (manuscripts in preparation). This study supports our hypothesis that Phyto V7 stimulates the immune system and serves as a significant stimulus for further exploring the potential of using Phyto V7 as a component of vaccination protocols.

\section{References}

1. Kong X, Wu G, Yin Y (2011) Roles of phytochemicals in amino acid nutrition. Front Biosci (Schol Ed) 3: 372-384.

2. Holst B, Williamson $\mathrm{G}$ (2008) Nutrients and phytochemicals: from bioavailability to bioefficacy beyond antioxidants. Curr Opin Biotechnol 19: 73-82.

3. Sun LZ, Currier NL, Miller SC (1999) The American coneflower: a prophylactic role involving nonspecific immunity. J Altern Complement Med 5: 437-446.

4. Tan BK, Vanitha J (2004) Immunomodulatory and antimicrobial effects of some traditional chinese medicinal herbs: a review. Curr Med Chem 11: 1423-1430.

5. Kapusta-Duch J, KopeÄ $\ddagger$ A, Piatkowska E, Borczak B, LeszczyÅ„ska T (2012) The beneficial effects of Brassica vegetables on human health. Rocz Panstw Zakl Hig 63: 389-395.

6. Skinner MA, Loh JM, Hunter DC, Zhang J (2011) Gold kiwifruit ( Actinidia chinensis 'Hort16A') for immune support. Proc Nutr Soc 70: 276-280.

7. Chen Q, Liu Z, He JH (2009) Achyranthes bidentata polysaccharide enhances immune response in weaned piglets. Immunopharmacol Immunotoxicol 31 253-260.

8. Aggarwal BB, Shishodia S (2004) Suppression of the nuclear factor-kappaB activation pathway by spice-derived phytochemicals: reasoning for seasoning. Ann N Y Acad Sci 1030: 434-441.

9. Hoensch H, Oertel R (2012) [Anti-inflammatory effects of tea-flavonoids]. Dtsch Med Wochenschr 137: 2738-2740.

10. Spiller F, Alves MK, Vieira SM, Carvalho TA, Leite CE, et al. (2008) Antiinflammatory effects of red pepper (Capsicum baccatum) on carrageenan- and antigen-induced inflammation. J Pharm Pharmacol 60: 473-478.

11. Liljebjelke KA, King DJ, Kapczynski DR (2008) Determination of minimum hemagglutinin units in an inactivated Newcastle disease virus vaccine for clinical protection of chickens from exotic Newcastle disease virus challenge. Avian Dis 52: 260-268.

12. Kapczynski DR, Martin A, Haddad EE, King DJ (2012) Protection from clinical disease against three highly virulent strains of Newcastle disease virus after in ovo application of an antibody-antigen complex vaccine in maternal antibodypositive chickens. Avian Dis 56: 555-560.

13. Kapczynski DR, Wise MG, King DJ (2006) Susceptibility and protection of naive and vaccinated racing pigeons (Columbia livia) against exotic Newcastle disease virus from the California 2002-2003 outbreak. Avian Dis 50: 336-341.

14. Kapczynski DR, King DJ (2005) Protection of chickens against overt clinical disease and determination of viral shedding following vaccination with commercially available Newcastle disease virus vaccines upon challenge with highly virulent virus from the California 2002 exotic Newcastle disease outbreak. Vaccine 23: 3424-3433. 